\title{
Monetary Policy and Short-Term Real Rates of Interest
}

\author{
R. W. HAFER and SCOTT E. HEIN
}

$\mathrm{T}$ EXTBOOK descriptions of the channels of monetary policy's impact on the economy usually outline a two-step procedure: "The first is that an increase in real balances generates a portfolio dis. equilibrium - at the prevailing interest rate and level of income, people are holding more money than they want. This causes portfolio holders to attempt to reduce their money holdings by buying other assets, thereby changing asset yields. In other words, the change in the [real] money supply changes [real] interest rates. The second stage of the transmission process occurs when the change in interest rates affects aggregate demand."1

The rational expectations literature, however, has raised serious questions about this description, especially the first stage wherein an increase in real money balances lowers expected real interest rates. Shiller, for example, drawing from previous work in rational expectations, hypothesizes that the expected real interest rate is unaffected by changes in monetary policy.?

While Shiller found little support for this hypothesis, other recent empirical work supports it. Fama, for instance, is unable to reject the hypothesis that the expected real rate on short-term financial assets was constant over much of the post-Accord period in the United States. ${ }^{3}$ This hypothesis is even

Thudiger Dornbusch and Stanley Fiseher, Macroeconomics (McGraw-Hill, 1978), p. 120.

"Robert J. Shiller, "Can the Fed Control Real Interest Rates?" in Stanley Fischer, ed. Rational Expectations and Economic Policy (The University of Chicago Press, 1980), pp. 117-56. Shiller also ontlined two other (non-exclusive) hypotheses: (1) the Fed can affect real rates only through unexpected policy moves and (2) Fed policies known far enough ahead of time have no effect on real rates. These bypotheses are not as stringent as the hypothesis considered in this paper.

PEugene F. Fand, "Short Term Interest Rates as Predictors of Inflation," American Economic Review (June 1975), pp. 269-82. stronger than Shiller's. It holds that monetary actions, as well as everything else, have had no systematic effect on expected real interest rates.

This article re-evaluates the evidence suggesting that the expected (ex ante) real interest rate on shortterm financial assets is constant. Evidence is prom vided that allows us to reject this hypothesis for the 1955-79 period. Following this, data are examined to determine whether evidence supports the typical textbook description in which changes in expected real interestrates are associated with changes in real money growth.

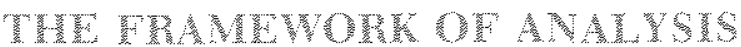

Consider first the relationship between nominal interest rates and inflation expectations embodied within the so-called Fisher relationship, ${ }^{4}$

(1) $i_{\mathrm{t}}=\mathrm{r}_{\mathrm{f}}^{\mathrm{e}}+\dot{\mathrm{P}}_{\mathrm{t}}^{\mathrm{e}}$;

where $i_{t}$ is a nominal (or market) rate of interest (the rate measuring how many dollars must be repaid in the future for a given dollar loaned today), $\mathrm{r}_{\mathrm{t}}^{\mathrm{e}}$ is the expected real interest rate (the rate measuring how

\footnotetext{
\$The beltef in a positive relation ship between expected inflation and nominal interest rates has a long history in economics. Henry Thomton recognized the relationship as early as 1811 . Alfed Marshall also atonowledged the link furing the latter hall of the 19 th century. Even so, the intensity with which Irving Fisher examined the relationship during his career has resulted in the distinetion of equation 1 being dubbed the "Fisher equation." See Hemry Thonton, "Two Speeches of Henry Thornton, esq. on the Bullion Report, May 1811 " in F. A. v. Hayek, ed., An Enquiry in to the Nature and Effects of the Paper Credit of Great Britain (1802). (Angust M. Kelley, 1962), pp. 323-62; Alfred Marshall, "Remedies for Fluctuations of General Prices (1887)," in A.C. Pigon, ed, Memorials of Alfred Marhall (Kelley \& Millmam, Inc., 1956 ) pp. 188.211; and Irwing Fisher, The Theory of Interest (Kelley \& Millman, Tre, 1954), especially Chapter 2 .
} 
many more goods can be obtained in the future by foregoing consumption today) and $\dot{P}_{t}^{e}$ is expected inflation (the rate at which the dollar price of goods is expected to rise.) Equation 1 represents a hypothesized equilibrium relationship. It posits thatchanges in observed nominal rates of interest fully reflect changes in expected inflation, holding the expected real rate constant. ${ }^{5}$ In other words, nominal rates and expected inflation are positively related and, ceteris paribus, move on a one-to-one basis.

The foundation for this equilibrium relationship is the view that investors have two possible investment opportunities: they can invest either in capital goods that produce a future stream of consumption goods or in financial assets denominated in monetary terms. Investment in capital goods is expected to produce $r_{t}^{e}$ percent more consumption goods per year than the amount of consumption goods originally given up to produce the capital good. To make the return on investing in the capital good comparable to the alternative investment (the financial asset), the value of the future stream of consumption goods must be translated into dollar terms. This is accomplished by adding the expected rate of change in the dollar price of consumption goods $(\dot{\mathrm{P}})$ to the rate of increase of consumption goods ( $\mathrm{r}$ ). The right-hand side of equation 1 , therefore, represents the expected dollar return from investing in a capital good.

In equilibrium (and without differential tax rates), the dollar return from investing in capital goods should equal the dollar return from investing in financial assets, measured by the nominal interest rate, $i_{t}$. Equation 1 thus states that an individual should not find the dollar yield on financial assets any different from the expected dollar yield on capital goods. We stress that equation 1 is an equilibrium condition: not only are the financial and capital goods markets hypothesized to be individually in equilibrium, but any differential in the expected real yields in these two markets is arbitraged away.

In its present form, equation 1 cannot be examined empirically because the two variables on the righthand side, the expected real rate of interest and inflation expectations, are not directly observable. While there are many observable nominal interest rates on financial assets, there are no reliable aggregate measures of either the expected real yield on

\footnotetext{
5This equilibrim relationship also should include the crossproduct tem $x_{\xi}^{e} \dot{\boldsymbol{p}}_{t}^{\mathrm{e}}$. Like most empirical analyses of this relationship, we ignore this tem, assuming that the magnitude of the variable is sufficienty small.
}

capital goods or the expected future inflation rate. ${ }^{6}$

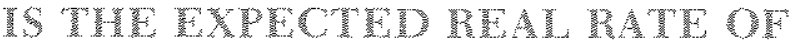 WNTREST CONSWAN?}

To test the relationship specified by equation 1 , one can make two assumptions: First, assume that the expected real interest rate is a constant, such that (2) $\mathrm{r}_{\mathrm{t}}^{\mathrm{e}}=\overline{\mathrm{r}}$.

Second, to circumvent the problem of measuring inflation expectations, assume that next period's actual inflation $\left(\dot{\mathrm{P}}_{\mathrm{t}+1}\right)$ is equal to what is currently expected (at time $t$ ), plus a random disturbance $\mu_{t+1}$, where $\mu_{\mathrm{i}+1}$ is independent and distributed $\mathrm{N}\left(0, \sigma^{2}\right)$;

(3) $\dot{\mathrm{P}}_{\mathrm{t}+1}=\dot{\mathrm{P}}_{\mathrm{t}}^{\mathrm{e}}+\mu_{\mathrm{z}+\mathrm{I}}$.

This relationship specifies that one-period-ahead inflation forecasts are unbiased; on average the actual inflation rate over the next time period will be the expected rate.

Substituting equations 2 and 3 into 1 yields

(4) $\mathrm{i}_{\mathrm{t}}=\overline{\mathrm{r}}+\dot{\mathrm{P}}_{\mathrm{t}+1}-\mu_{\mathrm{t}+1}$.

This equation can be arranged to test empirically the hypothesis that today's interest rate accurately predicts tomorrow's inflation as follows:

(5) $\dot{\mathrm{P}}_{\mathrm{t}+1}=-\overline{\mathbf{r}}+\beta_{0} \mathrm{i}_{\mathrm{t}}+\mu_{\mathrm{t}+1}$.

Assuming that financial markets are efficient, we would expect to find $\beta_{0}$ not to be statistically different from unity and the estimated constant term to be negative. If the estimated coefficient $\beta_{0}$ is not statistically different from unity, the proposition that current interest rates fully reflect the market's anticipations of the future inflation rate cannot be rejected. Similarly, if the estimated constant term is negative, the expected real rate of return is then positive as suggested by the underlying economic theory. More-

\footnotetext{
"Some researchers have attempted to investigate the relation ship by using directly observed in tation expectations data generated from Joseph A. Livingston's biamual survey of economists. See, for example, William $\mathrm{E}$. Gibson, "Interest Rates and Inflationary Expectations: New Evidence," American Economic Review (Decembet 1972), pp. 854-65; David H. Pyle, "Observed Price Expectations and Interest Rates," Review of Economies and Statistics (Angust 1972), pp. 275-80; Kajal Lahiri, "Inflationary Expectations: Their Formation and Interest Rate Effects," American Eronomic Retiew (March 1976), pp. 124-31; Thomas F. Cargill, "Anticipated Price Changes and Nominal Interest Rates in the 1950"s" Review of Economics and Statistics (August 1976), pp. 364-67; John A. Carlson, "Short-Term Interest Rates as Predictors of Enfation: Comment," American Economic: Review (June 1977), pp. 469-75; and Douglas K. Pearce, "Comparing Survey and Rational Measures of Expected Infation: Forecast Performance and Interest Rate Effects," Journal of Money, Credit and Banking (November 1979), pp. 447-56.
} 
Table 1

Empirical Estimates of Equation $5^{1}$

\begin{tabular}{|c|c|c|c|c|}
\hline Coefferent & $1 / 955 / 1 / 979$ & $1 / 19551 \mathrm{V1959}$ & $11960 / 1 / 969$ & 11970411970 \\
\hline \multicolumn{5}{|c|}{ Ordinary Least-squares Estimates } \\
\hline Constant & $\begin{array}{r}0580 \\
(146)\end{array}$ & $\begin{array}{r}2686 \\
(310)\end{array}$ & $\begin{array}{r}1,496 \\
(265)\end{array}$ & $\begin{array}{r}1393 \\
(42)\end{array}$ \\
\hline$B_{0}$ & $\begin{array}{r}1056 \\
(1349)\end{array}$ & $\begin{array}{l}0041 \\
(0 / 3)\end{array}$ & $\begin{array}{l}1073 \\
097)\end{array}$ & $\begin{array}{l}0840 \\
(561)\end{array}$ \\
\hline$R^{2}$ & 0.646 & 0055 & 0616 & 0439 \\
\hline$S E$ & 1630 & 190 & 116 & 1750 \\
\hline $\mathrm{ow}$ & 102 & 163 & 192 & 109 \\
\hline \multicolumn{5}{|c|}{ Generalized Least-Squares Estimates } \\
\hline Constant & -0126 & $\begin{array}{l}2584 \\
(268)\end{array}$ & $\begin{array}{l}1,496 \\
(2.65)\end{array}$ & $\begin{array}{l}1586 \\
(15)\end{array}$ \\
\hline$\rho_{0}$ & 0957 & $\begin{array}{l}0.001 \\
(0000)\end{array}$ & $(1073$ & $\begin{array}{l}0797 \\
(393)\end{array}$ \\
\hline$R$ & 0389 & 0056 & 0616 & 0270 \\
\hline SE & 1,424 & 1169 & 1116 & 1573 \\
\hline DW & 221 & 215 & 192 & 204 \\
\hline a & 0504 & 0190 & 0000 & 0,455 \\
\hline
\end{tabular}

T2 represents the coefficient ol detemnation adjusted for degrees of freedon, SE is the regres sion standard error, DW is the Durbin-Watson test statistic and $\rho$ is the estinate of the at tocorre lation coefficient Absolite value of 1 -statistics appear h parentheses.

over, the existence of serial correlation in the residuals would deny the assumption embodied in equation 3 and, consequently, would lead to a rejection of the hypothesis specified in equation $5 .^{7}$

Previous empirical studies generally have not explicitly considered the temporal stability of the expected real rate within this framework. The constant term in equation 5 represents the estimate of the (negative value of the) expected real rate of returm. The above theoretical foundation for this specification suggests that, in addition to be ing negative, this tem is statistically time-invariant. Thus, a test of the temporal stability of the constant term is also a test of the constancy of the expected real interest rate.

Table 1 presents estimates of equation 5 for various periods. The inflation data used to estimate equa-

\footnotetext{
${ }^{7}$ Fama tested and rejected the bypothesis that the expected reat rate was inearly related to expected inflation. Critical examinattions of Fanats restult are found in Carlson, "Short-Term Interest Ratess as Predictors of Inflation": Douglas Foines, "Short-Term Interest Rates as Predictors of Inflation: Comment" American Economic Review (Itune 1977), pp. 476-77, and Charles $\mathrm{R}$. Nelson and G. William Schwert, "Short-Term Interest Rates as Predictors of Inflation: On Testing the Hypothesis that the Real Rate of lnterest is Constant,"American Economic Review (June 1977), pp. 478-86. Also, see Fugene $F$. Fana, " Interest Rates and Infation: "lhe Message in the Entrails," American Economic Review (June 1977), pp. 487-96.
}

tion 5 are based on quarterly observations of the GNP deflator, expressed as annual rates of change. ${ }^{8}$ Since the GNP dellator provides an average measure of prices over the quarter, the quarterly average three-month Treasury bill rate is used as the nominal interest rate measure.

Consider first the results obtained by estimating equation 5 over the full sample period, I/1955IV/1979. The constant term is negative (although not significantly different from zero), and the coefficient on the interest rate variable is not statistically different from unity as suggested by the theory. Unfortunately, the low Durbin-Watson statistic provides evidence of first-order serial correlation. ${ }^{9}$

"The GNP delator is used to avoid reent problems with the consumer price index. For a discussion of problems with this index, see Alan S. Blinder, "The Consmer Price Index and the Mequarement of Recent Inflation," Brookings Papers on Economic Acticity (2:1980), pp. 539-65.

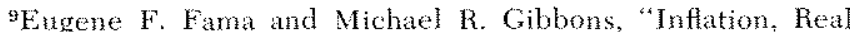
Refums and Caipital luvestment," Working Paper No dl (Graduate School of Business, Univetsity of Chicago, 1980), also find evidence of serialy correlated disturbance terms when quaterly data ate employed. In addition, in that study as well ats in his "Stock Returns, Real Activity, Inflation, and Money," American Economic Review (September 1981), pp. 545-65, Fama drops the assumption that the expected real rate of interest is constant. Both studies estimate the inflation/interest rate relationship assaming that the expected real rate is a random walk 
This result, by itself, is enough to reject the framework in equation $5 .{ }^{10}$ Focusing solely on the constancy of the expected real rate, however, the accompanying estimation problem can be corrected by using generalized least-squares estimation. These results appear in the lower half of table 1.

The full sample results reported there again indicate that next period's rate of inflation does mirror, one-for-one, a rise in today's interest rates. Moreover, the constant term remains insignificantly different from zero.

Table 1 further reports estimation results for subperiods arbitrarily truncated at the end of each decade. If the expected real rate of interest is tem. porally invariant, the constant terms in these subperiods should not differ statistically. Yet, as the table immediately shows, they do differ significantly across the various subperiods shown. In fact, the estimated constant term is positive and significant in the first subperiod (late 1950s), while not different from zero in the last decade (1970s). It has the anticipated negative sign only in the decade of the 1960 s. Moreover, the coefficient on the interest rate variable is not statistically different from zero in the late 1950 s, even though theory suggests that it should equal unity. Thus, the coefficient estimates, as well as summary statistics such as the $\overline{\mathrm{R}}^{2}$ and the standard errors of the equation, vary substantially across subperiods, irrespective of the estimation technique used.

The statistical significance of the variation in the constant term (the estimate of the ex ante real interest rate) can be investigated by including dummy variables for possible shifts in the intercept. Thus, equation 5 was re-estimated with two dummy variables: D1 equal to 1 for I/1955-IV/1959 and D2 equal to one for U/1960-IV/1969. Estimating such an equation with ordinary least squares again yielded residuals that were significantly autocorrelated. To improve hypothesis testing, the equation was estimated using a generalized least-squares routine to correct for assumed first-orderautocorrelation. The I/1955-IV/1979 estimation results are (absolute value of $\mathrm{t}$-statistics in parentheses):

$$
\begin{aligned}
& \text { (5) } \dot{\mathrm{P}}_{\mathrm{t}+1}=\begin{array}{l}
1.40-0.88 \mathrm{D} 1-1.88 \mathrm{D} 2+0.83 \mathrm{i}_{\uparrow} \\
(1.62) \quad(1.19) \quad(3.46) \quad(6.51)
\end{array} \\
& \overline{\mathrm{T}}^{2}=0.55 \quad \mathrm{SE}=1.37 \quad \mathrm{DW}=2.07 \quad \hat{\rho}=0.35
\end{aligned}
$$

\footnotetext{
${ }^{10}$ For market efficiency, past values of the disturbanee, since they are past infation forecast errors and are therefore known, should provide no additional help in assessing future infation beyond that already incomorated in matket interest rates. See Fama, "Short-Tenn Interest Rates," 13. 273, for a discussion of this aspect.
}

These results support the previous subperiod findings: the estimated real interest rate is significantly positive only in the $1960 \mathrm{~s}$. The point estimates of the expected real interest rate for the $1950 \mathrm{~s}, 1960 \mathrm{~s}$ and $1970 \mathrm{~s}$, respectively, are $-0.52,+0.48$ and -1.40 . While the point estimates for the $1950 \mathrm{~s}$ and the $1970 \mathrm{~s}$ are negative, they are not significantly different from zero. On the other hand, the positive point estimate for the $1960 \mathrm{~s}$ is significantly different from zero. Thus, the hypothesis that the expected real interest rate has been constant over the past 25 years must be rejected.

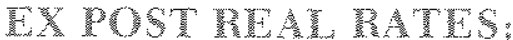 PURTIIIT CONSTANCY WTS}

Equation 4 can be rewritten as

(6) $i_{t}-\dot{p}_{t+1}=\bar{r}-\mu_{t+1}$.

This equation states that the ex post real rate should equal a constant (the $x$ ante real rate), minus a white noise random error term. ${ }^{11}$ A feel for the statistical variation in the real rate can be obtained by plotting its behavior for our sample period. Chart 1 shows the quarterly ex post real rate for the $\mathrm{I} / 1955-\mathrm{IV} / 1979$ period and its mean values for the I/1955-IV/1959 $(-0.03), \mathrm{I} / 1960-\mathrm{IV} / 1969(1.21)$ and $\mathrm{I} / 1970-\mathrm{IV} / 1979$ $(-0.39)$ subperiods. If equation 6 holds for the whole period, the means across subperiods should be equal, since the expected value of the disturbance term in each subperiod is zero.

Tests for equality of the ex post real interest rate means across the subperiods provide another investigation of the constancy hypothesis. Such tests again lead to a rejection of this hypothesis. The t-statistic,

\footnotetext{
1 This measure of the ex pest real rate is somewhat different from that used by others. Many take the difference between today's interest mates and loday inflation tate as an ex post real rate measure. Theory suggests, however, that the preferable measure is the difference between todur's interest rates and tomorrow's intation.

In the test subsequently developed and others which follow, interest rates are assumed to adjust one-for-one with intation expectations, a hypothesis that can be rejected in equation 5 '. The reader should be cantioned that there are counter theoretical arguments and some empirical evidence to suggest that the rature of the U.S. $\operatorname{tax}$ system las invalidated this relazr tionship, with interest rates rising more than one-for-one with an increase in intation expectations. For theoretical discus. sions, see Michael R. Darby, "The Financial and Tax Effects of Monetary Policy on Interest Rates," Economic Mncuiry (June? 1975), pp. 266-76; and Martin Feldstein, "Fnfation, Income Taxes, and the Rate of Interest: A Theoretical Analysis," American Economic Review (December 1976), pp. 809-20. For empirical evidence on the matter, see John A. Carlson, "Expected Inflation and Interest Rates," Economit: Inquiry (October 1979), pp. 597-608.
} 
Chart 1

Short-Term Ex Post Real Rate of Interest

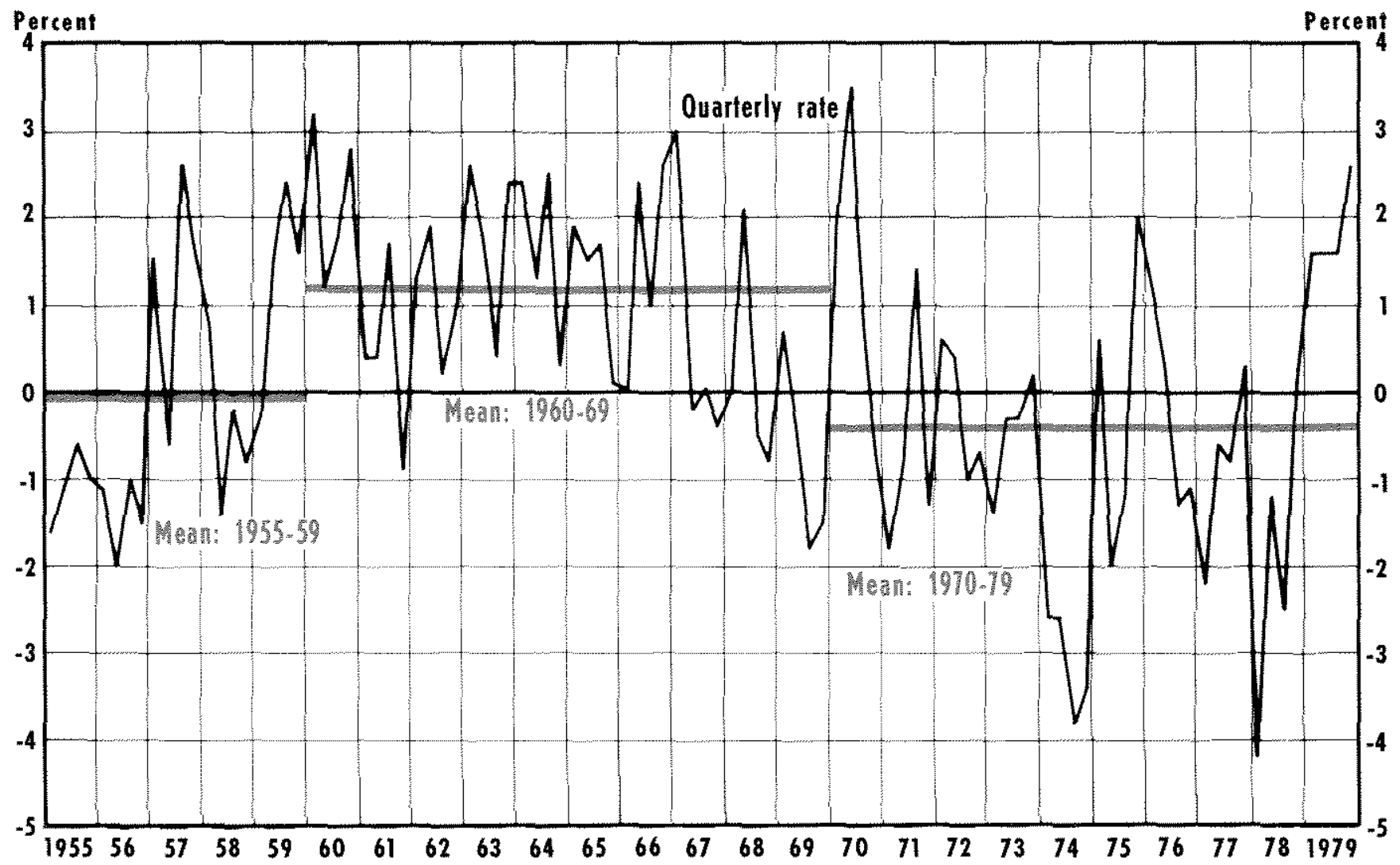

used to test whether the mean ex post real rate for the latter hall of the $1950 \mathrm{~s}$ is equal to that of the $1960 \mathrm{~s}$, is 3.67 , sufficiently large to reject the null hypothesis at the 5 percent significance level. Further, the t-statistic used to test the equality of mean ex post real rates in the 1960 s relative to the $1970 \mathrm{~s}$ is 4.86 , again allowing rejection of the null hypothesis of constant real interest rates at the 5 percent level. Thus, if one accepts the propositions that interest rates move in direct proportion with expected inflation and that inflation expectations are unbiased, one must reject the constancy of the $e x$ ante real interest rate over the subperiods investigated.

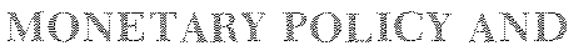

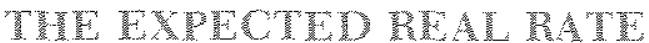

These findings suggest that the real interest rate has not been constant over the past 25 years. In this light, is there any evidence that links the real rate of interest to monetary policy? After all, the textbook description of monetary policy's transmission mechanism relates changes in the real rate to changes in real money balances. In particular, it maintains that an increase in real money balances lowers expected real rates, at least temporarily.

The previous framework, linking ex post and ex ante real rates, can be used to address this issue. If inflation expectations are unbiased and financial markets are efficient, then the ex post real rate $\left(i_{t}-\dot{P}_{t+1}\right)$ is equal to the ex ante real rate $\left(\mathrm{r}_{t}\right)$, minus a random disturbance term $\left(\mu_{t+1}\right)$ capturing unexpected inflation:

(7) $i_{t}-\dot{p}_{t+1}=r_{t}^{e}-\mu_{t+1}$.

The typical textbook relationship can be represented as

(8) $r r_{t}^{e}=\beta_{0}+\beta_{1}\left(M_{1} / P_{t}\right)+\beta_{2}\left(M_{t, 1} / P_{t-1}\right)+\ldots+\epsilon_{t}$

where $\mathrm{M}$ is the nominal money stock, $\mathrm{P}$ is the price 
level and $\epsilon$ is a random error term. This relationship represents the hypothesis that the expected real rate is related to real money balances. Since nothing in macroeconomic theory indicates how long it takes for changes in monetary policy to have an effect, lagged real balances are included in an effort to capture empirically the dynamics of the process. Theory does suggest, however, that some of the coefficients should be significantly negative. While it is impossible to estimate equation 8 because of a lack of observations on $r_{t}^{\mathrm{e}}$, equation 7 indicates that we have a close approximation in the ex post real rate. Combining equations 7 and 8 , we get

$$
\text { (9) } \begin{aligned}
\mathrm{i}_{\mathrm{t}}-\dot{\mathrm{P}}_{\mathrm{t}+\mathrm{1}} & =\beta_{0}+\beta_{1}\left(\mathrm{M}_{\mathrm{l}} / \mathrm{P}_{\mathrm{t}}\right)+\beta_{2}\left(\mathrm{M}_{\mathrm{t}-\mathrm{l}} / \mathrm{P}_{\mathrm{t}-\mathrm{l}}\right)+\ldots+\epsilon_{\mathrm{t}} \\
& -\mu_{\mathrm{t}+\mathrm{l}} .
\end{aligned}
$$

Equation 9 was estimated initially by arbitrarily trying 10 lags on real money balances in the relationship. Regardless of the sample period considered, however, the only coefficients that were statistically diflerent from zero in any consistent fashion were those for the contemporaneous and first-lagged real money balances. Thus, results including only these two variables are reported.

Estimates of equation 9 over the full sample period (1/1955-IV/1979) and most subperiods provide evidence of significant first-order autocorrelation in the residuals. Consequently, the relationship was reestimated using a generalized least-squares technique to correct for this problem. The resulting fullsample coefficient estimates and summary statistics are (absolute value of t-statistics in parentheses): ${ }^{12}$

$$
\begin{aligned}
& \text { (10) } \mathrm{E}_{\mathrm{t}}-\mathrm{P}_{\mathrm{t}+1}=5.00-0.89(\mathrm{M} / \mathrm{P})_{\mathrm{t}}+0.83(\mathrm{M} / \mathrm{P})_{\mathrm{t}-\mathrm{I}} \\
& (1.73) \quad(2.68) \quad(2.48) \\
& \overline{\mathrm{R}}=0.07 \mathrm{SE}=1.37 \mathrm{DW}=2.14 \hat{\rho}=0.56 \mathrm{~F}(2,97)=4.95
\end{aligned}
$$

While the variation in the ex post real rate explaned by the equation is small, it is statistically significant. Moreover, the coefficient estimates are consistent with the textbook transmission mechanism. An increase in real money balances is associated with a statistically significant, contempo-

\footnotetext{
${ }^{12}$ Money (M/P) is measured (in billions of 1972 dollars) by the adjusted monetary base for all results reported here. Thus, the empirical results indicate that a 81 billion increase in real balances will reduce the real interest rate by 89 basis points in the current period. "This rectine is of set, however, by an 83 basis-point increase in the real rate in the subsequent period. We also tried the M1 measure and obtaned similar results.
}

raneous decline in short-term real rates during this period. Further, the results are consistent with the long-rum policy ineffectiveness of increasing real balances to reduce real interest rates. ${ }^{13}$ The coefficient estimate for real money balances lagged one period is significantly positive and is not statistically different from the absolute value of the coefficient on contemporaneous real money balances. This finding indicates that a current increase in real money balances will be associated with a current decline in real rates, but followed by a rise in real rates of equal size at time $\mathrm{t}+\mathrm{l}$. This suggests that monetary authorities, to the extent that they can change real balances, cannot permanently affect real rates of interest.

While earlier evidence showed that the ex post real rate $\left(i_{t}-\dot{P}_{t+1}\right)$ behaved differently across subperiods, there is little evidence to suggest that its relationship to real money balances has changed over the period. For example, a conventional Chow test evaluating a hypothesized break in the relationship at IV/1969 yields a calculated F-statistic of $F(3,94)=0.39$, well below the 5 percent critical value of 2.70 . Thus, the regression coefficients are not statistically different before or after IV/1969:4 Changes in real balances have the same statistical effect on real interest rates across the sample period.

Finally, it is appropriate to note that the estimated relationship implies a positive relationship between the volatility in real money balances and the volatility in real interest rates. If the trequency of change in real money balances increases, the estimated relationship implies an increase in the frequency of change in real interest rates. The evidence presented here suggests that more stable real money growth, even over periods as short as a quarter, will produce a more stable pattern of real interest rate movements. ${ }^{15}$

\footnotetext{
1.3We do not mean to suggest that monetary anthorities can control real money balances over long periods of time. On this point, see Denis S. Kamosky, "Real Money Balances: A MisJeading Indicator of Monetary Aations," this Revied (February 1974) , pp. $2-10$.

$141 \mathrm{n}$ addition, we tested the hypothesis that the variance of the error term was larger in the 1970 s than n the earlier period. The calculated F-statistic (with 37 and 57 degrees of freedom, respectively) was 1.44 , less that the 5 percent critical value of 1.59. Thus, the hypothesis of equal variance across these two periods camot be rejected.

is An interesting investigation into the effects of monetary policy on both short- ind longterm real interest rates is provided in Dean $W$. Hughes and Dume Weimer, "The Impact on Business Investruent of the Federal heserve System's Operating Procedures," Fedenal Reserve Bank of Kansas City Economic Reviow (February 1982), pp. 14-25
} 


\section{CONCWUSON}

This article has provided evidence counter to the hypothesis that the expected real rate of return on short-term financial assets was constant over the period 1955-79. If such a hypothesis were valid, monetary policy would be powerless in affecting real economic activity through the conventional transmission mechanism. While rejecting the constancy hypothesis, this article also provides evidence consistent with conventional macroeconomic theory whereby increases in real money balances temporarily lower expected real rates. This effect is contemporaneous on a quarterly basis. While such an effect is significant, it is relatively small and is offset in the following quarter by an identical rise in expected real rates. Thus, there is no evidence of a long-run effect running from changes in real money balances to changes in real interest rates. Finally, the evidence presented here suggests that more volatile shortwun real money growth is likely to produce more volatile real interest rate fuctuations. Thus, contrary to recent claims, stable money growth and stable interest rates are hardly inconsistent policy objectives. ${ }^{16}$

16For another view, see Bryon Higgins, "Should the Federal Reserve Fine Tune Monetary Growth?" Federal Reserve Bank of Kansas City Economic Review (January 1982), pp. 3-16.

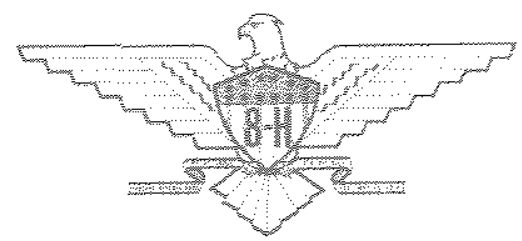

